\title{
BOEKBESPREKINGEN
}

\section{Mensenrechten in Nederland ${ }^{*}$}

\author{
Karin Arts
}

Barbara Oomen (2014) Rights for Others: The Slow Home-Coming of Human Rights in the Netherlands. Cambridge: Cambridge University Press. 229 pagina's, $€ 87,99$, ISBN 9781107041837.

Mensenrechten spelen al lange tijd een prominente rol in het buitenlands beleid van Nederland. De prioriteiten binnen dit beleid zijn al sinds 1979 formeel vastgelegd in verschillende beleidsnota's. Daarbij doet zich een opvallende, en in nationale mensenrechtenkringen breed bekritiseerde, paradox voor: hoewel mensenrechten een sterk Nederlands 'exportproduct' zijn, speelden zij tot voor kort in binnenlandse discussies en het binnenlandse beleid nauwelijks een expliciete rol. Pas relatief recent begon hier langzaam verandering in te komen. Zo startte het College voor de Rechten van de Mens in oktober 2012 zijn werkzaamheden (zie onder andere College voor de Rechten van de Mens 2014) als het nationale mensenrechteninstituut dat Nederland - volgens de 'Paris Principles' van de Verenigde Naties uit 1993 - al veel eerder geacht werd te hebben. In december 2013 werd het eerste Nationaal Actieplan Mensenrechten gelanceerd (Ministerie van Binnenlandse Zaken en Koninkrijksrelaties 2013). Op lokaal niveau heeft een aantal steden (zoals Den Haag, Middelburg en Utrecht) zichzelf opgeworpen als mensenrechtensteden. Ook komt er steeds meer aandacht voor de kritiek die Europese gerechtelijke instanties en regionale en VN-mensenrechtenorganen hebben op bepaalde situaties in Nederland, zoals de behandeling van mensen zonder verblijfsvergunning (inclusief vreemdelingendetentie en gebrek aan 'bed, bad en brood') en discriminatie op basis van geslacht, ras of etnische achtergrond. In haar boek Rights for Others: The Slow Home-Coming of Human Rights in the Netherlands beschrijft en analyseert Barbara Oomen de inhoud en achtergronden van voornoemde paradox. Haar keuze voor een analyse van deze problematiek in Nederland werd onder andere ingegeven door het feit dat veel van de al bestaande literatuur op dit terrein zich richt op ontwikkelingslanden of op 'common law'landen. Onderzoek naar de situatie en ontwikkelingen in het relatief rijke en goed ontwikkelde 'civil law' Nederland is daarop een relevante aanvulling. Oomen was in het algemeen uit op grotere duidelijkheid over hoe internationale mensenrechten al dan niet concreet betekenis krijgen op nationaal niveau, en volgens welke mechanismen en processen dit al dan niet gebeurt. Aldus ging zij op zoek naar antwoorden op de volgende, voor haar centrale specifiekere vragen: Hoe, wanneer, waarom en door wie wordt er een beroep gedaan op internationale mensen-

* $\quad$ Deze boekbespreking werd eind maart 2015 afgerond. 
rechten bij het benaderen van sociale en politieke problemen in een land zoals Nederland? Hoe heeft nationale implementatie van internationale mensenrechten in Nederland tot nu toe vorm gekregen? En welke betekenis heeft dit alles voor de bredere sociologie van rechten? Dat deze zaken niet zonder slag of stoot gaan, wordt duidelijk wanneer Oomen spreekt over 'the contested home-coming of human rights' (onder andere op p. 2).

In hoofdstukken 2 en 3 begint Oomen haar zoektocht met een schets van de historische ontwikkeling van de Nederlandse grondwetsbepalingen over mensenrechten, het gebrek aan bekendheid met deze bepalingen onder de Nederlandse bevolking, en de relatieve afwezigheid van publiek en politiek debat erover en over mensenrechten in Nederland in bredere zin. Daarna behandelt zij een aantal concrete kwesties die overtuigend illustreren hoe weinig het mensenrechtenkader in Nederland wordt gebruikt, en welke dynamieken daar achter zitten. Aan bod komen de pogingen om mensenrechteneducatie een solide plek te laten vinden in Nederland, bijvoorbeeld in de leerdoelen en curricula voor het basis- en middelbaar onderwijs (hoofdstuk 4), de zaak-Wilders (hoofdstuk 5), de aanpak van huiselijk geweld in Nederland (hoofdstuk 6), economische en sociale rechten (hoofdstuk 7) en de SGP-zaak (hoofdstuk 8). Oomen presenteert en analyseert deze kwesties op treffende wijze, gebruikmakend van een rijke methodologie die klassieke juridische analyse van het recht (inclusief de historische achtergrond van bijvoorbeeld wetgeving of jurisprudentie) combineert met kwantitatieve en kwalitatieve gegevens die zijn vergaard via enquêtes, interviews, veldonderzoek en observaties.

Zoals in haar meeste andere academische werk kiest Oomen ook in dit boek voor een sociaalwetenschappelijke analyse van het recht. De relevante juridische kaders, maar vooral ook de rechtscultuur, kwesties van juridisch bewustzijn ('legal consciousness') en de rol van verschillende actoren komen uitgebreid aan de orde. Daarbij put Oomen onder meer uit de (sub)disciplines rechtsgeleerdheid, rechtssociologie, rechtsantropologie en politieke wetenschappen. Haar persoonlijke ervaringen als beleidsadviseur en mensenrechtenactivist, bijvoorbeeld als lid van de Commissie Mensenrechten van de Adviesraad Internationale Vraagstukken, als lid van de Staatscommissie Grondwet en als voorzitter van het Platform Mensenrechteneducatie, leverden ook rijk materiaal op voor dit boek. De keuze om vanuit een 'insider'-perspectief, op basis van die persoonlijke ervaringen, een deel van dit boek te schrijven levert een zeer leesbaar en levendig boek op. Hier en daar heeft dat echter mogelijk ook een keerzijde en is het de vraag of Oomen lezers die niet ingewijd zijn in de problematiek die zij behandelt, of weinig ingewijd zijn in de Nederlandse context, steeds voldoende informatie geeft. Zo wordt een aantal keren in het boek verwezen naar fenomenen als 'polderdemocratie', Wilders, zijn film Fitna of de biblebelt, terwijl de basisuitleg erover pas later in het boek volgt. Ook wordt bepaalde jurisprudentie soms slechts summier omschreven (voor voorbeelden zie p. 112, de verwijzing naar de Van Dijke-zaak op p. 114 of de verwijzing naar de Ramsahai-zaak op p. 136). Dit maakt het - met name voor niet-ingewijde lezers, lijkt mij - soms moeilijk om de strekking en het belang van die fenomenen en jurisprudentie op waarde te schatten. 
Hoewel de rol van verschillende actoren in detail besproken wordt, inclusief de invloed die bepaalde individuen (zoals parlementsleden, vertegenwoordigers van non-gouvernementele organisaties (ngo's) en ambtenaren) kunnen hebben, hanteert Oomen in dit boek een vrij beperkte opvatting van het maatschappelijk middenveld ('civil society') en vult zij dat vooral in als vertegenwoordigers van mensenrechten-ngo's. De rol van het bredere publiek c.q. de publieke opinie, en zeker ook de rol van media, blijven ietwat onderbelicht. De recente verwikkelingen rondom Zwarte Piet, die tot een voorlopig hoogtepunt kwamen nadat dit boek geschreven was, onderstrepen de rol die zowel die publieke opinie als de sociale en traditionele media (de laatste bijvoorbeeld in de vorm van het Sinterklaasjournaal) kunnen hebben op het debat over mensenrechten in Nederland. Een mooie casus voor vervolgonderzoek dus!

Oomens analyse maakt door het boek heen uitgebreid duidelijk dat de 'slow homecoming' van mensenrechten in Nederland een complex proces is. De traditionele gedachte in Nederland dat mensenrechten vooral een exportproduct zijn en dus in het buitenlands beleid thuishoren, is nog steeds sterk en uitgebreid aanwezig. Het lage niveau van juridisch en breder bewustzijn ten aanzien van mensenrechten in Nederland onder politici, bestuurders, relevante andere professionals (zoals medwerkers van het Openbaar Ministerie of rechters), het maatschappelijk middenveld en het algemene publiek speelt een grote rol en roept regelmatig weerstand op tegen het benoemen van bepaalde problemen als mensenrechtenkwesties. Denk opnieuw maar aan de kwestie Zwarte Piet of bijvoorbeeld aan uitingen van discriminatie of racisme in Nederland, die door velen nog steeds ontkent worden. Het fenomeen coalitiepolitiek in de Nederlandse polderdemocratie - waarbij geven en nemen en consultatie tussen een veelheid aan diverse actoren centraal staan - verklaart ook voor een deel de traagheid waarmee mensenrechten in Nederland hun plek vinden. Dan zijn er tekortkomingen in het juridisch kader, waardoor bijvoorbeeld tot nu toe in Nederland nogal wat internationaal vastgelegde sociale en economische mensenrechten rechtstreekse werking is ontzegd. Toch ziet Oomen duidelijke lichtpunten sinds 2010: de oprichting van het al aan het begin van deze bespreking genoemde College voor de Rechten van de Mens in 2012 en de omarming van 'rights talk' door Nederlandse gemeenten zijn positieve ontwikkelingen.

Aan het eind van een prachtig boek stelt het concluderende hoofdstuk 9 overigens wel een klein beetje teleur. Het geeft een adequaat overzicht van de bevindingen van de verschillende hoofdstukken, maar het punt van de eventuele algemenere inzichten die deze bevindingen opleveren ten aanzien van de sociologie van rechten - toch een van de centrale vragen die Oomen aan het begin van haar boek formuleerde - wordt afgedaan in slechts anderhalve pagina (p. 204-205). Ook dit smaakt naar meer.

\section{Literatuur}

College voor de Rechten van de Mens (2014) Mensenrechten in Nederland 2013: Jaarlijkse rapportage. Utrecht: College voor de Rechten van de Mens. 
Karin Arts

Ministerie van Binnenlandse Zaken en Koninkrijksrelaties (2013) Nationaal Actieplan Mensenrechten: bescherming en bevordering van mensenrechten op nationaal niveau. Den Haag: Ministerie van Binnenlandse Zaken en Koninkrijksrelaties. 